\title{
Good News for Value Stocks: Further Evidence on Market Efficiency
}

\section{Citation}

LaPorta, Rafael, Josef Lakonishok, Andrei Shleifer, and Robert Vishny. 1997. Good News for Value Stocks: Further Evidence on Market Efficiency. Journal of Finance 52, no. : 859-874. doi: 10.1111/j.1540-6261.1997.tb04825.x

\section{Published Version}

10.1111/j.1540-6261.1997.tb04825.x

\section{Permanent link}

http://nrs.harvard.edu/urn-3:HUL.InstRepos:30725119

\section{Terms of Use}

This article was downloaded from Harvard University's DASH repository, and is made available under the terms and conditions applicable to Other Posted Material, as set forth at http:// nrs.harvard.edu/urn-3:HUL.InstRepos:dash.current.terms-of-use\#LAA

\section{Share Your Story}

The Harvard community has made this article openly available.

Please share how this access benefits you. Submit a story.

Accessibility 
NBER WORKING PAPER SERIES

GOOD NEWS FOR VALUE STOCKS:

FURTHER EVIDENCE ON MARKET

EFFICIENCY

Rafael La Porta

Josef Lakonishok

Andrei Shleifer

Robert Vishny

Working Paper 5311

\section{NATIONAL BUREAU OF ECONOMIC RESEARCH \\ 1050 Massachusetts Avenue \\ Cambridge, MA 02138 \\ October 1995}

We thank Gene Fama and Steve Kaplan for helpful comments. Financial support was provided by the National Science Foundation, the Bradley Foundation, and the National Bureau of Economic Research Asset Management Research Advisory Group. This paper is part of NBER's research program in Asset Pricing. Any opinions expressed are those of the authors and not those of the National Bureau of Economic Research.

(C) 1995 by Rafael La Porta, Josef Lakonishok, Andrei Shleifer and Robert Vishny. All rights reserved. Short sections of text, not to exceed two paragraphs, may be quoted without explicit permission provided that full credit, including () notice, is given to the source. 


\title{
GOOD NEWS FOR VALUE STOCKS:
}

FURTHER EVIDENCE ON MARKET

EFFICIENCY

\begin{abstract}
This paper examines the hypothesis that the superior return to so-called value stocks is the result of expectational errors made by investors. We study stock price reactions around earnings announcements for value and glamour stocks over a 5 year period after portfolio formation. The announcement returns suggest that a significant portion of the return difference between value and glamour stocks is attributable to earnings surprises that are systematically more positive for value stocks. The evidence is inconsistent with a risk-based explanation for the return differential.

Rafael La Porta

Department of Economics

Harvard University

Cambridge, MA 02138

Josef Lakonishok

Department of Finance

College of Commerce and

Business Administration

University of Illinois

1206 South Sixth Street

Champaign, IL 61820

and NBER

Robert Vishny

Andrei Shleifer

Department of Economics

Littauer Center 315

Harvard University

Cambridge, MA 02138

and NBER

Graduate School of Business

University of Chicago

1101 East 58th Street

Chicago, IL 60637

and NBER
\end{abstract}




\section{Introduction}

Most finance researchers agree that simple value strategies based on such ratios as bookto-market, earnings-to-price and cash flow-to-price have produced superior returns over a long period of time. ${ }^{2}$ Interpreting these superior returns, however, has been more controversial. On one side, Fama-French (1992) argue that these superior returns represent compensation for risk along the lines of the Merton (1973) ICAPM where portfolios formed on book-to-market ratios are interpreted as mimicking portfolios that are correlated with relevant state variables representing consumption or production opportunities. On the other side, Lakonishok, Shleifer and Vishny (LSV, 1994) contend that there is little evidence that high book-to-market and high cash-flow-to-price stocks are riskier based on conventional notions of systematic risk. LSV argue instead that these so-called value stocks have been underpriced relative to their risk and return characteristics due to various behavioral and institutional factors.

A specific behavioral explanation pursued in more depth by LSV (1994) is that the superior return on value stocks is due to expectational errors made by the market. In particular, investors tend to extrapolate past growth rates too far into the future. Evidence going back to Little (1962) suggests that earnings are close to a random walk, with earnings growth rates being predictable only one to two years in the future. Yet the large price-earnings ratio differences between value and glamour stocks seem to reflect an expectation that past growth differences will persist much longer than is reliably predictable from past data. Value stocks provide superior returns in the future because the market slowly realizes that earnings growth rates for value stocks are higher than it initially expected and conversely for glamour

${ }^{2}$ For example, see Basu (1977); Rosenberg, Reid and Lanstein (1984); De Bondt and Thaler (1985, 1987); Jaffe, Keim and Westerfield (1989); Chan, Hamao and Lakonishok (1991); Fama and French (1992); Lakonishok, Shleifer and Vishny (1994); and Davis (1994). For an alternative view that the superior returns are the result of survivor biases, see Banz and Breen (1986) and Kothari, Shanken and Sloan (1992). 
stocks. While such extrapolative expectations may not be the only source of mispricing, at least they represent a testable alternative hypothesis.

In this paper, we examine the role of expectational errors in explaining the superior return to value stocks. As in Chopra, Lakonishok and Ritter (1992) and La Porta (1993), we examine the market's reaction to earnings announcements to determine whether investors make systematic errors in pricing. We test whether earnings surprises in the 5 years after portfolio formation are systematically positive for value firms and negative for glamour firms. This is a direct test of the expectational errors hypothesis. These earnings announcement reactions are also interesting because they reveal the time pattern of the market's learning about the future prospects of value and glamour firms. Because the superior returns to value strategies persist

for at least 5 years (perhaps with some petering out toward years 4 and 5) we would like to see a correspondingly long period over which positive earnings surprises for value stocks are realized.

The structure of the paper is as follows. Section II describes our earnings surprise methodology. Section III presents the basic results. Section IV asks whether the earnings surprise results can be reconciled with an entirely risk-based explanation of the return differential between value and glamour stocks. Section V concludes.

\section{Methodology}

Data on Wall Street Journal quarterly earnings announcement days (event days) become available on COMPUSTAT in 1971. For this reason, our sample period runs from 1971 through 1992. Our universe of firms consists of NYSE, AMEX and NASDAQ firms that appear on CRSP and COMPUSTAT with data available for certain income statement and balance sheet items. We exclude REITs, ADRs, closed-end mutual funds, foreign stocks, unit investment trusts and American trusts. 
To be included in our sample, the common stock of a U.S. firm must have a CRSP value of equity in December of year $t-1$ and June of year $t$. The firm must also have COMPUSTAT data on sales, earnings (before extraordinary items), cash flow, and book equity, where cash flow is defined as earnings plus depreciation. To minimize the possible impact of COMPUSTAT look-ahead bias (see Kothari, Shanken and Sloan (1995) and Chan, Jegadeesh and Lakonishok (forthcoming)) we require the firm to have COMPUSTAT data on sales and earnings for fiscal years ending in calendar $t-1$ through $t-5$. This ensures that we do not measure stock returns for the first 5 years that a firm's data appears on COMPUSTAT, since this data may have been back-filled and could not therefore serve as the basis for a measurable trading strategy available to market participants.

To examine earnings announcement return differences across value and glamour stocks, we form portfolios on the basis of two classifications: the book-to-market ratio favored by Fama-French (1992) and a two-way classification based on cash-flow-to-price and past growthin-sales introduced by LSV (1994). Portfolios are formed in June of each year $t$ using accounting data for fiscal year end in year $t-1$ and market value of equity from December of year $\mathrm{t}-1$. For the purposes of size classifications, market value of equity is measured at the end of June of year $t$.

Using the ratio of book equity to market value of equity in December of $t-1$, we sort stocks into deciles using all firms except those firms with negative book values of equity. The value portfolio consists of stocks in the highest decile of book-to-market (BM10) and the glamour portfolio consists of stocks in the lowest decile of book-to-market (BM1).

According to the two-way classification of LSV (1994), value stocks are defined as those stocks which have shown poor growth in the past and are expected by the market to continue growing slowly. Specifically, value stocks are defined as those stocks which have had low sales growth over the previous five years and currently trade for low multiples of current cash 
flow, presumably because of the market's pessimistic expectations for future growth (LSV, 1994). Each stock is ranked on cash-flow-to-price (CP) and on a weighted average of sales growth ranks (GS). The weighted sales growth measure starts by ranking each firm based on its sales growth in each year $t-5$ through $t-1$. The weighted average sales rank is then obtained by giving the weight of 5 to its sales growth rank in year $t-1$, the weight of 4 to its growth rate rank in year $\mathrm{t}-2$, etc. All stocks are divided into 3 groups (bottom $30 \%$ (1), middle $40 \%$ (2) and top 30\% (3)) based on CP and, independently, 3 groups based on GS. Groups formed on $\mathrm{CP}$ are based only on firms with non-negative cash flows at the time of formation. The glamour portfolio consists of those stocks ranked lowest on cash-flow-to-price (CP1) and highest on growth-in-sales (GS3), while the value portfolio consists of those stocks ranked highest on cash-flow-to-price (CP3) and lowest on sales growth (GS1).

For each of our portfolios we present two types of returns: annual buy-and-hold returns and earnings announcement returns. Annual buy-and-hold returns are reported for 5 years after formation with year 1 beginning in July of year $t$ and ending in June of year $t+1$. For stocks where returns data become unavailable between July of year $t$ and the end of June of year $t+1$, we replace the remainder of that period's return by the equally-weighted return on the remaining stocks in the portfolio. Annual portfolio returns are obtained by equallyweighting the returns on all stocks which belong to the portfolio at the beginning of July in year $\mathrm{t}$.

The focus of this paper is on the earnings announcement returns. These are measured quarterly over a 3-day window $(t-1, t+1)$ around the Wall Street Journal publication dates over a period of 5 years after portfolio formation. For each quarter, the 3-day, buy-and-hold event returns are equally-weighted across all stocks in the portfolio to compute a portfolio event return.

As a benchmark for the annual buy-and-hold returns, size-adjusted returns are calculated 
as follows. For each year, each stock in the sample is sorted into a size decile where size is measured as market capitalization of equity at the end of June of year $t$ and decile breakpoints are based on NYSE size decile breakpoints (excluding REITs, ADRs, etc.) Since a given size decile may contain a disproportionate number of value or glamour stocks (with the smallest size deciles typically containing a disproportionate number of value stocks), we make an attempt to purge any confounding value effects from our estimates of size-based returns (see Chopra, Lakonishok and Ritter (1992)). This is done by forming size decile benchmark portfolios using only firms that are classified as neither value nor glamour firms. For the book-to-market analysis, the size decile benchmark portfolios are equally-weighted portfolios consisting of all firms in that size decile which are also in deciles $4,5,6$ and 7 according to BM. For the (CP, GS) analysis, the size decile benchmark portfolios returns include all firms in the size decile except those classified as value (top $30 \%$ according to CP and bottom $30 \%$ according to GS) or glamour (bottom $30 \%$ according to CP and top $30 \%$ according to GS). Annual size-adjusted returns are calculated for each stock by subtracting off the return on its corresponding size decile benchmark portfolio for year $t$. The annual size-adjusted return for a portfolio is then obtained by equally-weighting the size-adjusted returns for all stocks in that portfolio.

Size-adjusted earnings announcement returns are calculated in a similar manner. For each quarter in the sample, a size-decile earnings announcement benchmark portfolio is formed using all stocks in that size decile for which earnings announcement dates are available and which are neither classified as value or glamour firms. The size-benchmark return is then just an equal-weighting of these earnings announcement returns. In other words, the benchmark used is not the average 3-day return for a firm of comparable size, but rather, the average 3day return in a $(-1,+1)$ window around that quarter's earnings announcements for firms in that size decile. 
Size-adjusted earnings announcement returns for each stock are calculated by subtracting off the return on its corresponding size decile earnings announcement benchmark. The sizeadjusted earnings announcement return for a portfolio is then obtained by equally-weighting the size-adjusted return for all stocks in that portfolio.

\section{Earnings surprises for value and glamour portfolios.}

Table 1 reports results on earnings announcement returns and annual buy-and-hold returns for value and glamour portfolios using the BM classification. Panel A contains the key results on earnings announcement returns over the 5 years after portfolio formation. The 20 quarterly portfolio earnings announcement returns (Q01-Q20) are equally-weighted 3-day, buy-and-hold returns calculated on all stocks for which data are available for that quarter. These are aggregated into annual intervals by summing up the four quarterly earnings announcement returns in each of the five post-formation years. For example, Q01-Q04 is the sample average over 22 formation periods (June 1971-June 1992) of the sum of the 4 quarterly earnings announcement returns occurring in the first year after portfolio formation, while Q17-Q20 is the analogous return for year 5 after formation.

The results indicate that event returns are substantially higher for the value portfolio than for the glamour portfolio. In year +1 , the cumulative event return is $-0.5 \%$ for the glamour portfolio, but is $+3.5 \%$ for the value portfolio, indicating a relative disappointment in the earnings performance of glamour stocks. The difference of $+4 \%$ realized over only 12 trading days represents one-third of the $12.2 \%$ total difference in first-year returns between the value and glamour portfolios reported in Panel C. The t-statistic for the difference between year +1 event returns between the value and glamour portfolio indicates that these differences are also highly significant. T-statistics are calculated using the method of Fama-MacBeth (1973) and assuming year-to-year independence of the earnings announcement return differences. For 
example, we have 22 independent observations on the difference between Q01-Q04 for the value portfolio and for the glamour portfolio, so we just perform a t-test with standard errors calculated from this time series.

Quantitatively similar results also obtain for year +2 . Substantially higher relative event returns for the value portfolio persist even 5 years after portfolio formation, although the magnitude of the difference in years +4 and +5 is approximately half of the year +1 and +2 differences. This evidence suggests that the positive updating on the earnings prospects of value stocks relative to glamour stocks takes place quite slowly. This fits well with the evidence on annual buy and hold returns, since those return differences between value and glamour portfolios also persist for 5 years. Annual buy-and-hold return differences appear to peter out more slowly than the earnings surprises, an issue we will revisit shortly.

Size-adjusted event returns tell a very similar story but with somewhat smaller magnitudes in every case. In year +1 , the difference in size-adjusted event returns between value and glamour portfolios is $+3.2 \%$, representing approximately $28 \%$ of the $11 \%$ total difference in annual size-adjusted returns between the value and glamour portfolios. Moreover, the sizeadjusted event return differences and the size-adjusted annual buy-and-hold return differences appear to peter out a little more quickly over time than the raw return differences.

Table 2 contains analogous numbers for the (CP, GS) classification. The results are similar. In year +1 , the difference in event returns across value and glamour portfolios is $+3.2 \%$ which represents approximately $27 \%$ of the difference in year +1 returns between the two portfolios. This difference is significant at the $1 \%$ level. The difference in event returns is still $2.0 \%$ in year +3 and represents approximately $20 \%$ of the $9.6 \%$ difference in annual returns between the two portfolios. Interestingly, both event return and annual buy-and-hold differences appear to die out more rapidly over time using the (CP, GS) classification. In fact, deterioration of annual return differences for the (CP, GS) classification is much more 
pronounced here than in the original LSV paper. We believe that this is due to the addition of NASDAQ firms as well as to a different sample period. In any case, the petering out of the earnings surprises is consistent with the petering out of annual return differences between the two portfolios. This petering out is especially evident in the size-adjusted annual return differences where year +5 return differences are significantly less than half those for year +1 .

Reconciling the time pattern of earnings surprises with the time pattern of annual buy-andhold returns is an interesting exercise. The finding that positive relative earnings surprises for value stocks, while relatively long-lived, appear to die out faster than annual buy and hold return differences suggests that earnings surprises are not the whole story behind the superior returns to value stocks. Other behavioral and institutional factors may play a role in the superior returns to value strategies (LSV, 1994).

Recall also that much learning about future earnings prospects takes place outside of earnings announcement dates and that such learning may take slowly after an initial piece of information is disclosed at announcement time. The important study by Bernard and Thomas (1989) documents a sizeable drift in returns after earnings announcements, which the authors attribute to slow assimilation of the initial information.

While not reported here in detail, we have performed a similar study of post-earnings announcement returns drift on our sample of value and glamour firms. In particular, we subdivide all stocks in the value and glamour portfolios into two subgroups, those with Q01 event returns above median for the portfolio and those below median. We then measure the return for each subgroup. The evidence suggests that both value and glamour portfolios exhibit drift similar to the results of Bernard and Thomas (1989), with returns drift in the same direction as the initial earnings surprise lasting for about 6 months after the announcement. Overall, the evidence suggests that learning about future earnings prospects is a slow process. Event returns, while perhaps a good measure of the direction of learning, pin down neither the 
magnitude nor even the precise time pattern of the learning about future prospects.

So far, we have focused on earnings announcement results for our entire NYSE/AMEX/ NASDAQ universe of firms. One interesting question is whether these results apply equally well to the larger firms which are more closely followed by market participants. These stocks would presumably be less vulnerable to the sort of mispricing discussed by LSV (1994). In fact, on a sample of NYSE and AMEX stocks only, LSV (1994) do find that the return differences between value and glamour stocks are approximately $30 \%$ lower on a subsample of firms with market capitalization above the median for the NYSE/AMEX CRSP universe.

Tables 3 and 4 present numbers analogous to those of Tables 1 and 2 for the subsample of the largest firms with market capitalization above the NYSE median in the year of portfolio formation. The difference in earnings announcement returns between value and glamour firms is substantially lower than in the full sample and also accounts for a lower fraction of the annual return difference between value and glamour portfolios. For example, using the bookto-market classification in Table 3, we see that the earnings announcement return difference between the value and glamour portfolios is $1.0 \%$ in year $+1,1.5 \%$ in year +2 , and $1.2 \%$ in year +3 . These differences represent approximately $12 \%, 14 \%$, and $11 \%$ respectively of the annual buy-and-hold return differences reported in Panel C of Table 3. Recall that for the full sample, the announcement return differences were $4.0 \%$ in year $+1,3.4 \%$ in year +2 , and $2.8 \%$ in year +3 . These represent ap-proximately $33 \%, 27 \%$, and $22 \%$ of the annual return differences reported in Panel $\mathrm{C}$ of Table 1.

One interpretation of these results is that the pricing of the larger firms is more efficient, leaving less systematic bias in the earnings surprises for value versus glamour firms. On the other hand, since these firms are followed more extensively by analysts and get much more coverage in the financial press, it may just be that a greater fraction of fundamental news about the larger firms is impounded into prices outside of quarterly earnings announcements. The 
Wall Street Journal and other business publications provide a constant stream of salient news and information about the larger firms, but not the smaller firms. Hence, for the larger firms the earnings announcement returns may be a less meaningful measure of earnings surprises. It is unclear what accounts for the earnings announcement return differences between large and small firms.

A related problem is that of late earnings announcements. It is widely believed that when a firm has not announced earnings when it was expected to, the news is more likely to be bad. Hence, for firms announcing late the earnings news may dribble out before the actual announcement date as the market observes that "the dog hasn't barked." This could be a source of potential bias in our results if value firms systematically announce bad earnings late more often than glamour firms, and this bad news is not captured in the $(-1,+1)$ window around the earnings announcement.

To evaluate this possibility, we defined all firms announcing late as those announcing more than 2 trading days after the calendar date of the announcement for the previous year (the expected date). For these firm-quarters, instead of using the $(-1,+1)$ return, we plugged in the return from 4 days before the expected date to 1 day after the actual announcement date to capture the effect of the market's learning from the announcement delay. While this introduces additional noise, the results give some indication of whether such a delayed announcement bias can account for our results. For the BM classification in Table 1, we find that $32 \%$ of value firms and $29 \%$ of glamour firms announce late. When we plug in the return over the extended window for all firms announcing late, we get an annual earnings announcement return for the value firms in year +1 of $3.2 \%$ compared to the $3.5 \%$ return reported in Table 1, indicating that the bias adjustment makes very little difference. In fact, the bias adjustment for the glamour firms is even of the theoretically wrong sign. The delayed announcement effect does not appear to explain the return difference between value and glamour firms around earnings 
announcements.

In sum, the evidence indicates that a significant portion of the return difference between value and glamour stocks is attributable to earnings surprises that are systematically more positive for value stocks.

\section{Do differences in event returns represent differences in risk premia?}

An ardent defender of the risk premium story might argue at this point that the foregoing event returns evidence is inconclusive. The sizeable differences in event returns between value and glamour portfolios may just represent differences in ex ante risk premia realized around a small number of important information events. If a disproportionately high fraction of the annual uncertainty about a stock is realized around quarterly earnings announcements, then perhaps a disproportionate share of the risk premium is as well. Since the risk premium for value stocks is higher, these stocks should exhibit higher event returns than glamour stocks.

Do the data support such an explanation? It does not appear so. Recall that the return on glamour stocks around earnings announcements in both years +1 and +2 after portfolio formation is actually negative. This is clearly not supportive of the risk view, unless one believes in ex ante negative risk premia on a large subset of stocks. On the other hand, the estimates are not sufficiently precise to reject the null hypothesis that the event return on glamour stocks is equal to the T-bill return. There is a more powerful test of the risk premium hypothesis, however. The risk premium view which maintains that earnings announcement days contain a disproportionately large fraction of a stock's risk premium, implies that, for both glamour and value stocks, event returns should be higher than non-event returns. In contrast, if the behavioral view is correct, and the information revealed about glamour stocks on event days is sufficiently negative, event returns could be significantly lower than non-event returns, despite a higher ex ante risk premium. A comparison of event returns and non-event 
returns for glamour stocks can potentially discriminate between these two views.

Table 5 presents the numbers for this test using both $\mathrm{BM}$ and (CP,GS) classifications. For each quarter in the sample, we run cross-sectional regressions of daily return for each stock on the value-weighted market return and a dummy variable for whether the day belongs to the $(-1,+1)$ window around that quarter's earnings announcement. Regressions are run separately for value and glamour stocks, with new value and glamour portfolios formed at the end of each June. As in Fama-MacBeth (1973), the coefficients reported are the averages of the coefficients from the 88 quarterly cross-sectional regressions (1971:2 - 1993:1) with standard errors computed according to the time series of those coefficients.

We begin with the results for the BM classification. Regressions for low BM (glamour firms) show an intercept of 1.3 basis points per day and a coefficient of 1.07 on the market return. More importantly, the coefficient on the event dummy is -6.6 basis points per day with a standard error of 1.9 basis points. On an annualized basis this difference in return is approximately $16 \%$ per year. Event day returns are significantly below non-event day returns despite the higher ex ante risk premium that should be required to hold stocks over event days. This result can only be explained by the hypothesis that, on average, the market received negative surprises for glamour stocks on earnings announcement days. Results for value stocks are also quite interesting. The mean event return for value stocks on event days is 19.4 basis points higher than the non-event return with a standard error of 3.6 basis points. On an annualized basis this difference is approximately $50 \%$ per year. This result is consistent with a very high risk premium realized on event days or positive earnings surprises for value stocks or some combination of the two.

Results for the (CP,GS) classification are similar, but perhaps less dramatic. Regressions for glamour stocks (low CP, high GS) show an intercept of 1.6 basis points per day, and a coefficient on the market return of 1.03 . The estimated return on event days is 4.0 basis points 
below the return on non-event days, with a standard error of 1.6 basis points. Regressions for value stocks show an estimated event day return that is 17.7 basis points above the non-event day return with a standard error of 2.5 basis points.

In sum, comparisons of event and non-event day returns do not support the risk premium explanation of the superior return on value stocks. The risk premium hypothesis implies that event returns should be higher than non-event returns for both glamour and value stocks. The data show that event returns are lower than non-event returns for glamour stocks despite the higher ex ante risk premium posited by the theory. This can only be explained by negative earnings surprises for glamour stocks.

\section{Conclusion}

The evidence in this paper suggests that expectational errors about future earnings prospects play an important role in the superior return to value stocks. Post-formation earnings announcement returns are substantially higher for value stocks than for glamour stocks. Event returns for glamour stocks are significantly lower than glamour returns on an average day, which is inconsistent with the risk premium explanation for the return differences between value and glamour stocks. In the full sample of NYSE, AMEX and NASDAQ firms, earnings announcement return differences explain approximately $25-30 \%$ of the annual return differences between value and glamour stocks in the first two to three years after portfolio formation and approximately $15-20 \%$ of return differences over years four and five after formation. Results for firms larger than the NYSE median are weaker, although this is possibly due to a tendency for widely-followed stocks to adjust to news more continuously rather than have information events heavily concentrated on quarterly earnings announcement days.

The persistence of positive relative earnings surprises for value stocks long after portfolio 
formation is consistent with the finding of various researchers that the superior returns to value stocks persist long after portfolio formation. However, the magnitude of earnings surprises does diminish more rapidly than the annual return differences, indicating that learning about future earnings prospects may not explain all of the difference in return between value and glamour stocks.

What does explain the long-lived component of these differences in expected return? LSV (1994) suggest various possibilities. First, investors may simply have a preference for investing in "good" companies with superior past growth records. Unsophisticated investors may equate a good company with a good investment irrespective of price. They may even perceive such companies to be less risky, as allegedly was the case with IBM before investors became convinced of its vulnerability. Unlike differences in growth rates, differences in levels of profitability across firms and industries are relatively long-lived. Finally, sophisticated institutional investors may gravitate toward well-known, glamour stocks because these stocks are much easier to justify to clients and superiors as prudent investments.

Unfortunately, it is difficult to distinguish these explanations from the risk view. What appears to be an irrational preference for holding glamour firms at a low expected return might be labeled as a conventional risk preference by others. LSV's approach has been to attempt to distinguish these views in two ways. First, they examine the distribution of returns to value and glamour stocks in search of the alleged source of portfolio risk. They study whether a value portfolio has a higher standard deviation, a higher beta, worse performance during recessions or worse performance during extreme down markets. According to these measures, value portfolios are, if anything, less risky than glamour portfolios (LSV, 1994). More work is needed to investigate other risk-based economic explanations for the superior returns to 
value stocks. ${ }^{3}$ Second, LSV have tried to provide direct evidence for the importance of institutional factors by examining the behavior of institutional investors toward value and glamour stocks. In a forthcoming working paper, LSV provide evidence that institutional investors have historically overweighted glamour stocks in their portfolios. This may be the simplest explanation for the aggregate underperformance of money managers relative to the S\&P 500 over the past 25-30 years.

${ }^{3} \mathrm{~A}$ recent paper by Daniel and Titman (1995) casts doubt on the risk factor interpretation of the superior returns to high book-to-market stocks. In particular, they find that, while high book-to-market stocks do have higher expected returns, expected returns are not significantly higher for stocks whose returns are more highly correlated with the book-to-market factor. In other words, comovement with the proposed risk factor does not explain expected returns. 


\section{References}

Banz, R. and W. Breen, 1986, Sample dependent results using accounting and market data: Some evidence, Journal of Finance, 41, 779-793.

Basu, S., 1977, Investment performance of common stocks in relation to their price earnings ratios: A test of the efficient markets hypothesis, Journal of Finance 32, 663-682.

Bernard, V. and J. Thomas, 1989, Post-earnings announcement drift: Delayed price response or risk premium, Journal of Accounting Research Supplement, 1-36.

Chan, L., Y. Hamao and J. Lakonishok, 1991, Fundamentals in stock returns in Japan, Journal of Finance 46, 1739-1764.

Chan, L., N. Jegadeesh and J. Lakonishok, forthcoming, Issues in evaluating the performance of value versus glamour stocks, Journal of Finance.

Chopra, N., J. Lakonishok and J. Ritter, 1992, Measuring abnormal performance: Do stocks overreact?, Journal of Financial Economics 31, 235-268.

Daniel, K. and S. Titman, 1995, Evidence on the characteristics of cross-sectional variation in stock returns, Mimeo, May.

Davis, J., 1994, The cross-section of realized stock returns: The pre-COMPUSTAT evidence, Journal of Finance 49.

De Bondt, W. and R. Thaler, 1985, Does the stock market overreact?, Journal of Finance 40, 793-805.

De Bondt, W. and R. Thaler, 1987, Further evidence on investor overreaction and stock market seasonality, Journal of Finance 42, 557-581.

Fama, E. and K. French, 1992, The cross-section of expected stock returns, Journal of Finance 47, 427-466.

Fama, E. and K. French, 1995, Size and book-to-market factors in earnings and returns, Journal of Finance 50, 131-156. 
Jaffe, J., D. Keim, and R. Westerfield, 1989, Earnings yields, market values, and stocks returns, Journal of Finance 44, 135-148.

Kothari, S.P., J. Shanken, and R. Sloan, 1995, Another look at the cross-section of expected stock returns, Journal of Finance 50, 185-224.

La Porta, R., 1993, Expectations and the cross-section of stock returns, Mimeo, Harvard University.

Lakonishok, J., A. Shleifer, and R. Vishny, 1994, Contrarian investment, extrapolation, and risk, Journal of Finance 49, 1541-1578.

Merton, R., 1973, An intertemporal asset pricing model, Econometrica 41, 867-887.

Rosenberg, B., K. Reid and R. Lanstein, 1984, Persuasive evidence of market inefficiency, Journal of Portfolio Management 11, 9-17. 
TABLE 1

Annual Cumulative Earnings Announcement Returns and Annual Buy-and-Hold Returns on Value and Glamour Portfolios Classified by Book-to-Market Ratios, 1971-1992

(Full Sample)

Glamour

BM
1

2
Value

9
Mean

Difference

$10-1$
T-Stat for

Mean Difference

10 - 1

PANEL A: Event Returns

$\begin{array}{lllllll}\text { RET Q01-Q04 } & -0.00472 & 0.00772 & 0.03200 & 0.03532 & 0.04004 & 5.65 \\ \text { RET Q05-Q08 } & -0.00428 & 0.00688 & 0.02828 & 0.03012 & 0.03440 & 7.14 \\ \text { RET Q09-Q12 } & 0.00312 & 0.00796 & 0.02492 & 0.03136 & 0.02824 & 5.12 \\ \text { RET Q13-Q16 } & 0.00804 & 0.00812 & 0.02176 & 0.02644 & 0.01840 & 3.67 \\ \text { RET Q17-Q20 } & 0.00424 & 0.01024 & 0.01368 & 0.02432 & 0.02008 & 4.49\end{array}$

PANEL B: Size-Adjusted Event Returns

$\begin{array}{lcccccc}\text { SAR Q01-Q04 } & -0.01595 & -0.00334 & 0.01533 & 0.01610 & 0.03205 & 5.03 \\ \text { SAR Q05-Q08 } & -0.01484 & -0.00419 & 0.01185 & 0.01216 & 0.02699 & 5.90 \\ \text { SAR Q09-Q12 } & -0.00822 & -0.00411 & 0.00812 & 0.01341 & 0.02162 & 4.18 \\ \text { SAR Q13-Q16 } & -0.00296 & -0.00318 & 0.00578 & 0.00945 & 0.01240 & 3.05 \\ \text { SAR Q17-Q20 } & -0.00484 & 0.00062 & 0.00013 & 0.00987 & 0.01471 & 3.39 \\ \text { PANEL C: Annual Returns } & & & & & \\ \text { RET YR1 } & 0.09254 & 0.14811 & 0.22534 & 0.21547 & 0.12292 & 3.84 \\ \text { RET YR2 } & 0.09284 & 0.14590 & 0.20085 & 0.21971 & 0.12686 & 3.88 \\ \text { RET YR3 } & 0.11979 & 0.14835 & 0.24195 & 0.24496 & 0.12517 & 4.27 \\ \text { RET YR4 } & 0.13063 & 0.16836 & 0.23149 & 0.25141 & 0.12078 & 3.82 \\ \text { RET YR5 } & 0.12274 & 0.17032 & 0.22329 & 0.23518 & 0.11244 & 3.11 \\ \text { PANEL D: Size-Adjusted Annual Returns } & & & & 3.96 \\ \text { SAR YR1 } & -0.07810 & -0.02196 & 0.04412 & 0.03213 & 0.11023 & 3.50 \\ \text { SAR YR2 } & -0.08011 & -0.02824 & 0.01569 & 0.03279 & 0.11289 & 3.91 \\ \text { SAR YR3 } & -0.06160 & -0.03947 & 0.03402 & 0.03426 & 0.09585 & 4.00 \\ \text { SAR YR4 } & -0.06130 & -0.03217 & 0.00610 & 0.02467 & 0.08597 & 2.78 \\ \text { SAR YR5 } & -0.05659 & -0.02101 & 0.00442 & 0.01803 & 0.07461 & 1.96\end{array}$


TABLE 2

Earnings Announcement Returns and Annual Buy-and-Hold Returns on

Value and Glamour Portfolios Classified by Cash-Flow-to-Price and Growth-in-Sales, 1971-1992 (Full Sample)

Glamour Value Mean T-Stat for

Difference Mean Difference

$\begin{array}{lll}\text { CP } & 1 & 3 \\ \text { GS } & 3 & 1\end{array}$

$10-1$

\section{PANEL A: Event Returns}

$\begin{array}{lllll}\text { RET Q01-Q04 } & -0.00019 & 0.03201 & 0.03201 & 6.62 \\ \text { RET Q05-Q08 } & 0.00122 & 0.02922 & 0.02800 & 4.14 \\ \text { RET Q09-Q12 } & 0.00581 & 0.02589 & 0.02008 & 4.20 \\ \text { RET Q13-Q16 } & 0.00843 & 0.02056 & 0.01213 & 3.69 \\ \text { RET Q17-Q20 } & 0.00898 & 0.01966 & 0.01068 & 2.89\end{array}$

PANEL B: Size-Adjusted Event Returns

SAR Q01-Q04

SAR Q05-Q08

SAR Q09-Q12

SAR Q13-Q16

SAR Q17-Q20
$-0.01130$

$-0.00997$

$-0.00526$

$-0.00202$

0.00025

PANEL C: Annual Returns
0.11790

0.12349

0.13979

0.15757

0.15758

RET YR5

RET YR2

RET YR3

RET YR4
3

$110-1$
PANEL D: Size-Adjusted Annual Returns

SAR YR 1

$-0.04562$

$-0.04064$

$-0.03826$

$-0.03185$

$-0.02262$
SAR YR2

SAR YR4

SAR YR5
0.01285

0.01112

0.00864

0.00444

0.00567

0.23700

0.24333

0.23534

0.24452

0.22269

0.05102

0.05436

0.02934

0.02511

0.01531
0.02415

5.31

3.21

3.08

2.45

1.66

$$
-0.02262
$$


TABLE 3

Annual Cumulative Earnings Announcement Returns and Annual Buy-and-Hold Returns on Value and Glamour Portfolios Classified by Book-to-Market Ratios, 1971-1992

(Firms with Market Cap > NYSE Median)

Glamour Value

BM
2

9
Mean

Difference Mean Difference

10 - 1

\section{PANEL A: Event Returns}

$\begin{array}{lllllll}\text { RET Q01-Q04 } & 0.00315 & 0.00976 & 0.01840 & 0.01348 & 0.01033 & 0.80 \\ \text { RET Q05-Q08 } & 0.00189 & 0.00662 & 0.01819 & 0.01717 & 0.01528 & 2.09 \\ \text { RET Q09-Q12 } & 0.00265 & 0.00649 & 0.01341 & 0.01468 & 0.01203 & 1.55 \\ \text { RET Q13-Q16 } & 0.00474 & 0.00633 & 0.00757 & 0.01172 & 0.00698 & 0.93 \\ \text { RET Q17-Q20 } & 0.00230 & 0.00569 & 0.00498 & 0.00182 & -0.00048 & -0.08\end{array}$

PANEL B: Size-Adjusted Event Returns

$\begin{array}{lllllll}\text { SAR Q01-Q04 } & -0.00417 & 0.00267 & 0.01118 & 0.00476 & 0.00893 & 0.69 \\ \text { SAR Q05-Q08 } & -0.00561 & -0.00056 & 0.01060 & 0.00946 & 0.01508 & 2.06 \\ \text { SAR Q09-Q12 } & -0.00566 & -0.00176 & 0.00545 & 0.00741 & 0.01296 & 1.71 \\ \text { SAR Q13-Q16 } & -0.00290 & -0.00110 & 0.00019 & 0.00470 & 0.00760 & 1.03 \\ \text { SAR Q17-Q20 } & -0.00321 & 0.00021 & -0.00091 & -0.00346 & -0.00025 & -0.04\end{array}$

\section{PANEL C: Annual Returns}

$\begin{array}{lcccccc}\text { RET YR1 } & 0.11850 & 0.13855 & 0.17810 & 0.19898 & 0.08047 & 1.77 \\ \text { RET YR2 } & 0.09456 & 0.13442 & 0.18220 & 0.20341 & 0.10884 & 2.83 \\ \text { RET YR3 } & 0.11630 & 0.14040 & 0.19985 & 0.22462 & 0.10831 & 2.97 \\ \text { RET YR4 } & 0.12053 & 0.15511 & 0.18150 & 0.21296 & 0.09243 & 3.32 \\ \text { RET YR5 } & 0.10921 & 0.15368 & 0.20022 & 0.20082 & 0.09160 & 2.76 \\ \text { PANEL D: Size-Adjusted Annual Returns } & & & & \\ \text { SAR YR1 } & -0.03286 & -0.01312 & 0.02334 & 0.04211 & 0.07497 & 1.68 \\ \text { SAR YR2 } & -0.06261 & -0.02261 & 0.02557 & 0.04220 & 0.10481 & 2.84 \\ \text { SAR YR3 } & -0.04951 & -0.02794 & 0.02596 & 0.05322 & 0.10272 & 2.99 \\ \text { SAR YR4 } & -0.05814 & -0.02656 & -0.00752 & 0.02648 & 0.08462 & 3.19 \\ \text { SAR YR5 } & -0.06009 & -0.01887 & 0.02488 & 0.02892 & 0.08901 & 2.93\end{array}$


TABLE 4

Earnings Announcement Returns and Annual Buy-and-Hold Returns on

Value and Glamour Portfolios Classified by Cash-Flow-to-Price and Growth-in-Sales, 1971-1992 (Firms with Market Cap > NYSE Median)

Glamour Value Mean

Difference

T-Stat for

$\begin{array}{lll}\text { CP } & 1 & 3 \\ \text { GS } & 3 & 1\end{array}$

3

$10-1$

$10-1$

\section{PANEL A: Event Returns}

$\begin{array}{lllll}\text { RET Q01-Q04 } & 0.00456 & 0.01683 & 0.01228 & 2.13 \\ \text { RET Q05-Q08 } & 0.00245 & 0.02634 & 0.02389 & 3.80 \\ \text { RET Q09-Q12 } & 0.00445 & 0.01337 & 0.00892 & 1.25 \\ \text { RET Q13-Q16 } & 0.00374 & 0.00798 & 0.00424 & 0.83 \\ \text { RET Q17-Q20 } & 0.00388 & 0.00459 & 0.00072 & 0.16\end{array}$

PANEL B: Size-Adjusted Event Returns

$\begin{array}{lllll}\text { SAR Q01-Q04 } & -0.00252 & 0.00872 & 0.01124 & 2.06 \\ \text { SAR Q05-Q08 } & -0.00487 & 0.01813 & 0.02300 & 3.68 \\ \text { SAR Q09-Q12 } & -0.00278 & 0.00544 & 0.00821 & 1.14 \\ \text { SAR Q13-Q16 } & -0.00308 & 0.00020 & 0.00328 & 0.63 \\ \text { SAR Q17-Q20 } & -0.00089 & -0.00145 & -0.00056 & -0.13 \\ \text { PANEL C: Annual Returns } & & & & \\ \text { RET YR1 } & 0.11840 & 0.19950 & 0.08109 & 2.58 \\ \text { RET YR2 } & 0.11089 & 0.19257 & 0.08168 & 2.61 \\ \text { RET YR3 } & 0.11857 & 0.19773 & 0.07916 & 3.45 \\ \text { RET YR4 } & 0.13551 & 0.20017 & 0.06465 & 2.11 \\ \text { RET YR5 } & 0.12846 & 0.20431 & 0.07584 & 2.57\end{array}$

PANEL D: Size-Adjusted Annual Returns

$\begin{array}{lllll}\text { SAR YR1 } & -0.02959 & 0.04722 & 0.07680 & 2.57 \\ \text { SAR YR2 } & -0.03972 & 0.03650 & 0.07622 & 2.55 \\ \text { SAR YR3 } & -0.04412 & 0.03377 & 0.07789 & 3.57 \\ \text { SAR YR4 } & -0.04048 & 0.02209 & 0.06257 & 2.05 \\ \text { SAR YR5 } & -0.03987 & 0.03480 & 0.07467 & 2.58\end{array}$


TABLE 5

Cross-Section Regression Tests of Difference between Event and Non-Event Returns for Value and Glamour Portfolios, 1971-1992

(Full Sample)

Intercept

\section{PANEL A: Regressions for Portfolios Formed on BM}

Low BM Portfolio Return

$$
0.000128
$$

(Glamour)

(2.00)

High BM Portfolio Return

0.001104

(6.77)
Event Day Dummy

$-0.000661$

$(-3.44)$

0.001945

(5.45)

Market Return

\section{PANEL B: Regressions for Portfolios Formed on (CP.GS)}

Low CP, High GS Portfolio Return

(Glamour)

High CP, Low GS Portfolio Return

(Value)
0.000161

(2.40)

0.000764

(7.35)
$-0.000399$

$(-2.56)$

0.001769

(7.05)
1.0670

0.6502

$(30.67)$
1.0276

(76.12)

0.6751

(32.30) 